\title{
Pembangunan Sistem Informasi Manajemen dan Pelayanan Konsumen PT. Air Minum Giri Menang (PERSERODA)
}

\author{
Rifqi Hammad ${ }^{1}$, Habib Ratu Perwira Negara ${ }^{2}$, Ahmad $^{3}$, Muhammad Arfa ${ }^{4}$, Lalu Erwin \\ Jannata Arhaditya ${ }^{5}$ \\ rifqi.hammad@universitasbumigora.ac.id ${ }^{1}$, habib.ratu27@gmail.com², \\ ahmad@universitasbumigora.ac.id ${ }^{3}$, Muhammad.arfa@universitasbumigora.ac.id ${ }^{4}$, \\ erwinjannata@gmail.com ${ }^{5}$ \\ 1,2,3,4,5 Universitas Bumigora
}

\begin{abstract}
Article History:
Received: 15-12-2021

Revised: 13-01-2022

Accepted: 14-01-2022
\end{abstract}

Keywords: Information System, Management, complaint, PT. Air Minum Giri Menang, Waterfall

\begin{abstract}
PT. Air Minum Giri Menang is a drinking water service provider company located in the city of Mataram. The existence of news media and information on consumer complaints is also one of the services provided by this company, where consumers can easily get updates from the latest news about drinking water services, but the management of this information is still somewhat inefficient because the categories of Latest News and Disturbance Information are still managed by a different admin. This activity is carried out by the service team as a form of applying knowledge to help the community. The method used is the Waterfall method which makes it easier to build the system to be achieved. The purpose of this activity is to build an information portal and complaint service, as well as build a system that can help admins from PT. Air Minum Giri Menang manages news information and consumer complaints in one place. Based on the results of the test cases, it can be concluded that the application can run well and in accordance with the desired results regardless of the type of device the application is accessed from.
\end{abstract}

\section{Pendahuluan}

Sistem informasi merupakan suatu sistem yang diterapkan oleh suatu organisasi untuk mengelola data menjadi informasi yang dibutuhkan oleh pengguna (Rubiani et al., 2021). Keberadaan sebuah Sistem Informasi yang baik mampu meningkatkan efisiensi pekerjaan dan pengambilan keputusan suatu perusahaan atau instansi yang menggunakannya (Sudjiman \& Sudjiman, 2020) serta dapat mengurangi adanya kesalahan dalam pengelolaan dan penyajian informasi (Anam et al., 2017). Pengaruh dari keberadaan Sistem Informasi tidak hanya terbatas pada perusahaan atau instansi saja, terkadang bahkan konsumen mereka ikut merasakan pengaruh positif dari adanya sebuah sistem informasi (Kadir, 2014).

Portal berita dan pelayanan aduan konsumen adalah salah satu jenis sistem informasi yang umum digunakan oleh sebuah perusahaan kepada konsumen mereka tak terkecuali perusahaan layanan air minum PT. Air Minum Giri Menang, akan tetapi proses 
pengelolaan informasi berita dan aduan konsumen ini masih kurang efisien, dikarenakan informasi berita dan informasi gangguan layanan perusahaan dikelola oleh admin yang berbeda dan melalui sistem yang berbeda. Pengelolaan informasi internal yang efisien sangat dibutuhkan agar proses alur data dalam perusahaan tidak terganggu (Dailami, 2018). Hal tersebut juga menyebabkan terlambatnya pihak manajemen mendapatkan informasi terkait aduan konsumen (masyakarat) yang mana dapat menimbulkan terjadinya keterlambatan dalam penangaan aduan konsumen oleh PT. Air Minum Giri Menang.

Berdasarkan permasalahan diatas, tim pengabdian bekerja sama dengan PT. Air Minum Giri Menang untuk membangun sebuah sistem manajemen informasi satu tempat yang lebih efisiesn sehingga pelayanan yang diberikan oleh PT. Air Minum Giri Menang kepada masyakarat dapat ditingkatkan dan juga sebagai bentuk pengabdian yang dilakukan oleh tim pengabdi dalam menerapkan ilmu yang bermanfaat bagi masyarakat. Dengan adanya sistem informasi tersebut diharapkan mampu mengelola informasi berita, gangguan air, dan aduan konsumen dalam satu tempat, yang mana dapat membantu mengurangi tenaga yang dibutuhkan dalam proses pengelolaan informasi. Selain itu, diharapkan konsumen dapat memantau perkembangan berita dan dapat melakukan pengaduan terhadap keluhan yang dialami.

Untuk mendukung kegiatan pembangungan sistem informasi ini, digunakan sebuah library pengembangan aplikasi berbasis web modern bernama ReactJS. ReactJS adalah proyek open-source dari Facebook yang membantu mengembangkan tampilan antar-muka aplikasi (Panjaitan \& Pakpahan, 2021). Pengembangan aplikasi dengan ReactJS lebih cepat dan efisien karena aplikasi dibangun dari komponen-komponen fungsional yang kemudian disatukan dalam sebuah Single Page Application (SPA) dan dapat digunakan kembali pada sistem yang sama. Berkat cara kerjanya, aplikasi berbasis ReactJS mampu menampung dan menampilkan data selama beberapa waktu tanpa memuat ulang halaman aplikasi (Rawat \& Mahajan, 2020).

\section{Metode}

Kegiatan pembangunan manajemen sistem infrormasi ini menggunakan tahapan dengan konsep PDCA (Plan, Do, Check dan Act). Konsep PDCA ini merupakan suatu proses yang berkelanjutan yang digunakan untuk mengembangkan atau memperbaiki sebuah sistem (Susanto et al., 2020) (Mulyono et al., 2020). Adapun tahapan PDCA yang digunakan pada kegiatan ini dapat dilihat pada Gambar 1. 


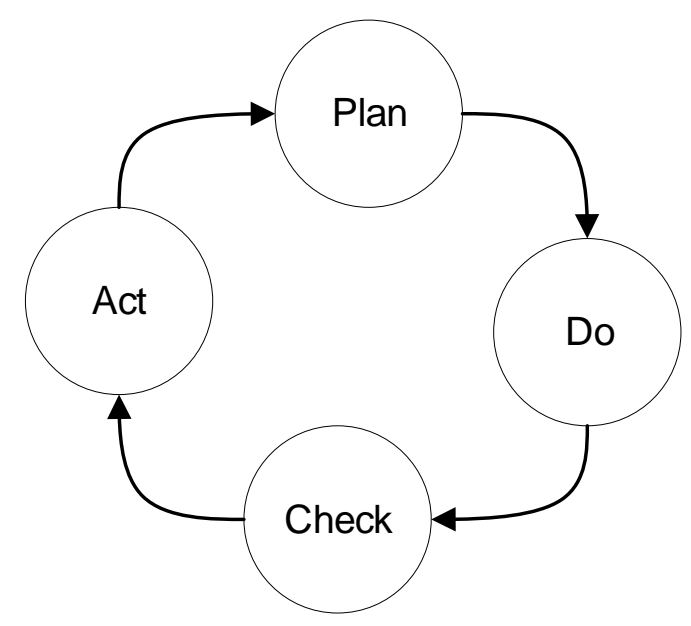

Gambar 1. Tahapan kegiatan

Gambar 1 menunjukkan tahapan yang dilakukan pada kegiatan ini. Pada gambar tersebut ditunjukkan terdapat 4 tahapan yaitu Plan (Perencanaan), Do (Kerjakan), Check (Evaluasi) dan Act (Tindak Lanjut).

1. Plan (Perencanaan)

Pada tahap ini, tim pengabdi mengajukan kerjasama dengan mitra yaitu PT. Air Minum Giri dan pada tahap ini juga ditentukan dari tujuan dilakukkannya kegiatan ini. Adapun tujuan dilakukannya kegiatan ini adalah untuk membangun sistem informasi manajemen dan pelayanan konsumen pada PT. Air Minum Giri Menang.

2. Do (Pengerjaan)

Pada tahap ini, tim pengabdi beserta mitra melakukan kegiatan yang telah direncanakan. Adapun kegiatan yang dilakukan pada tahap ini meliputi kegiatan yang dibutuhkan dalam pembangunan sistem informasi manajemen dan pelayanan konsumen seperti analisis, perancangan, implementasi dan lain-lain serta juga pelatihan penggunaan Sistem Informasi kepada mitra.

3. Check (Pengevaluasian)

Pada tahap ini dilakukan evaluasi terkait tujuan dilakukannya kegiatan ini beserta dengan prosesnya dan juga dilakukan evaluasi apakah Sistem Informasi yang dibagun dapat diterima atau tidak.

4. Act (Tindak Lanjut)

Pada tahap ini dilakukan evaluasi secara keseluruhan terhadap hasil tujuan yang telah ditetapkan sebelumnya dan juga pada tahap ini dilakukan proses perbaikan jika terdapat kesalahan yang ditemukan pada sistem. 


\section{Pembahasan}

\section{Planning}

Kegiatan pembangunan sistem informasi manajemen dan pelayanan konsumen pada PT. Air Minum Giri menang bertujuan untuk meningkatkan kualitas pelayanan yang dimiliki oleh PT. Air Minum Giri Menang terhadap masyarakat. Kegiatan ini dilakukan mulai dari tanggal 2 Agustus 2021 sampai dengan 31 Agustus 2021. Pada tahap planning ini juga dikumpulkan beberapa data dan informasi yang dibutuhkan dalam membangun sistem informasi tersebut. Pengumpulan data dilakukan dengan cara wawancara dengan bagian terkait, kemudian observasi proses bisnis yang sedang berjalan dan juga dengan mempelajari dokumen-dokumen terkait pelayanan konsumen.

\section{Do}

Pada tahap ini, proses pembangunan sistem informasi yang telah direncanakan, dilakukan. Tahap yang dilakukan pertama kali adalah melakukan instalasi penyimpanan data yang digunakan oleh sistem informasi tersebut. Adapun aplikasi media penyimpanan dari sistem informasi yang dibangun dapat dilihat pada Gambar 2.

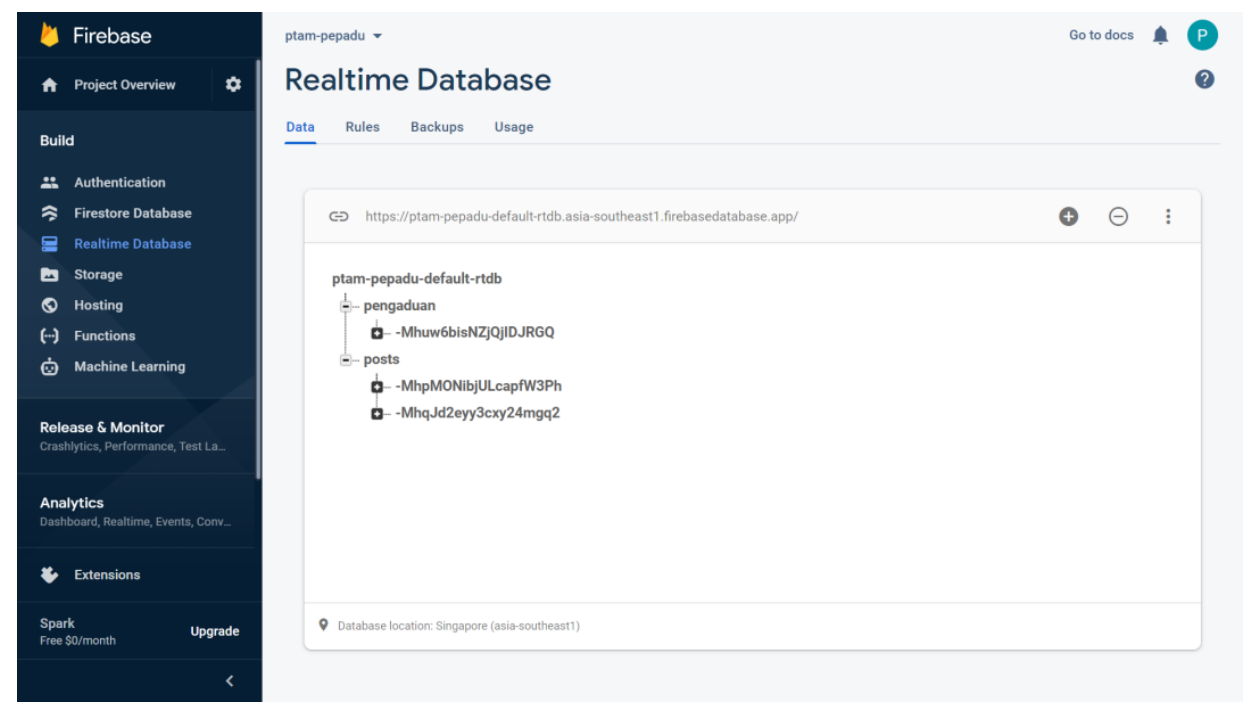

Gambar 2. Penyimpanan data dengan firebase

Gambar 2 menunjukkan media penyimpanan yang digunakan pada sistem informasi ini. Pada gambar tersebut dapat dilihat bahwa media penyimapan data yang digunakan bersifat cloud dari Google yaitu Firebase yang bersifat NoSQL. Setelah melakukan instalasi media penyimpanan datanya. Langkah selanjutnya adalah masuk ke halaman utama sistem informasi seperti yang dapat dilihat pada Gambar 3. 
ADMA

Gurnal Pengabdian dan Pemberdayaan Masyarakat
2022, Vol.2, No.2, pp.199-208

Doi: 10.30812/adma.v2i2.1616

(๑)

\section{KABAR PT. AIR MINUM GIRI MENANG (PERSERODA)}

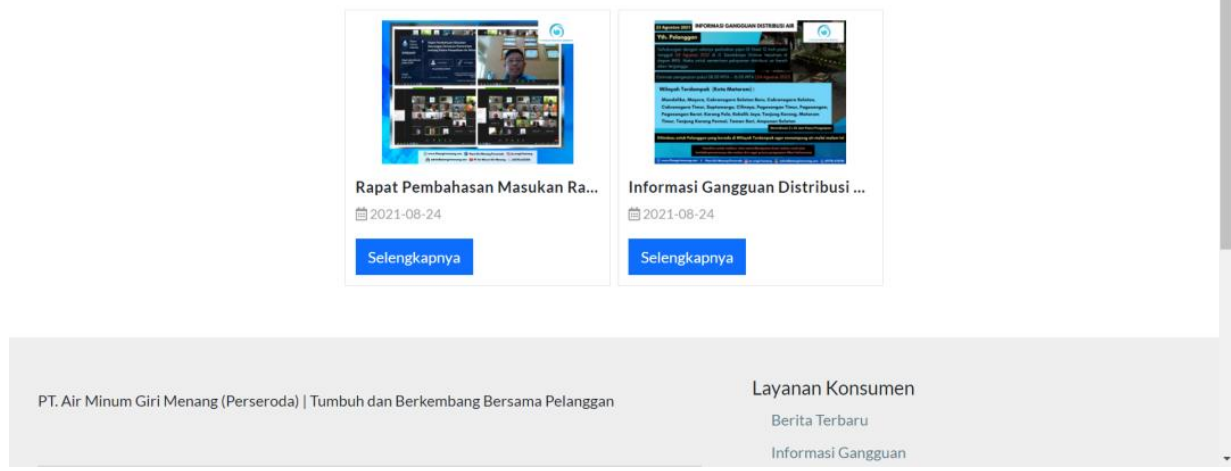

Gambar 3. Halaman utama

Gambar 3 menunjukkan halaman utama yang pertama kali muncul setelah mengakses sistem informasi. Untuk masyarakat yang ingin melakukan pengaduan terhadap layanan yang diberikan oleh PT Air Minum Giri Menang, pengguna dapat memilih menu layanan pengaduan pada halaman utama. Form layanan pengaduan dapat dlihat pada Gambar 4.

(6)

Input Data Pengaduan

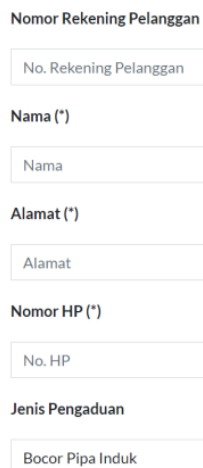

Gambar 4. Halaman input data pengaduan

Masyakarat perlu mengisi beberapa data seperti yang ditunjukkan pada Gambar 4. Setelah melakukan pengisian data aduan, sistem akan memberikan nomor aduan yang dapat digunakan untuk melakukan pelacakan terhadap aduan yang diajukan. Sehingga pada menu tracking aduan keluhan, masyakat tinggal memasukkan nomor yang telah didapatkan. Adapun menu tracking aduan keluhan dapat dilihat pada Gambar 5. 
ADMA

Durnal Pengabdian dan Pemberdayaan Masyarakat
2022, Vol.2, No.2, pp.199-208

Doi: 10.30812/adma.v2i2.1616

(ด)

Tracking Aduan Keluhan

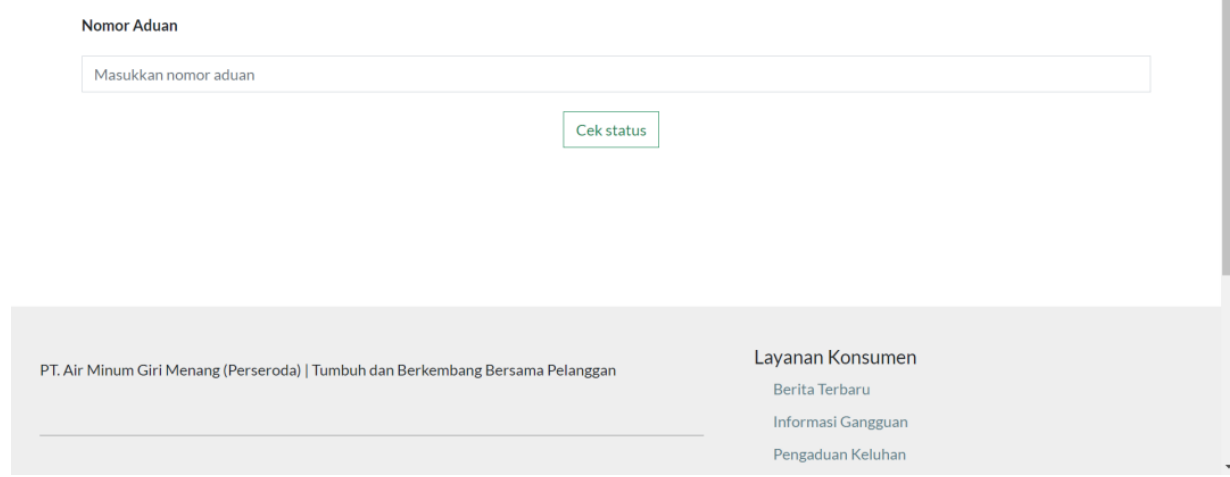

Gambar 5. Tracking aduan keluhan

Pengguna sistem informasi dapat mengelola data dan informasi pada sistem informasi tersebut. Namun harus melakukan login telebih dahulu kedalam sistem. Halaman login pada sistem informasi ini dapat dilihat pada gambar 6 .

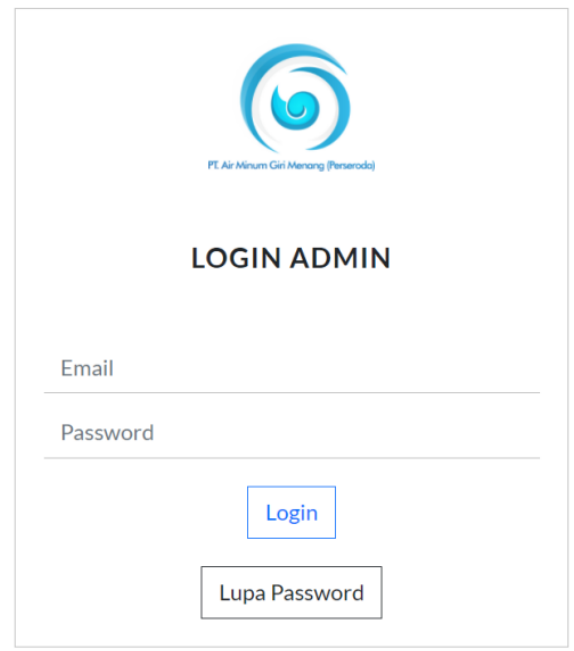

Gambar 6. Halaman login

Setelah melakukan login, pengguna akan masuk kedalam halaman dashboard dari sistem informasi manajemen ini. Terdapat beberapa menu dalam halaman dasborad ini tergantung dari hak askses yang dimiliki oleh pengguna. Salah satu menunya adalah mengelola berita atau pengumuman seperti yang ditunjukkan pada Gambar 7 . 


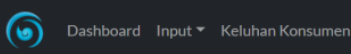

Input Post Terbaru

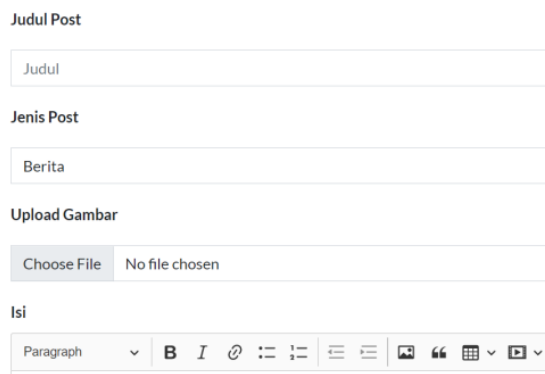

Gambar 7. Halaman input post

Selain menu untuk mengelola berita ada juga menu yang digunakan untuk melihat keluhan masyarakat seperti yang ditunjukkan pada Gambar 8.
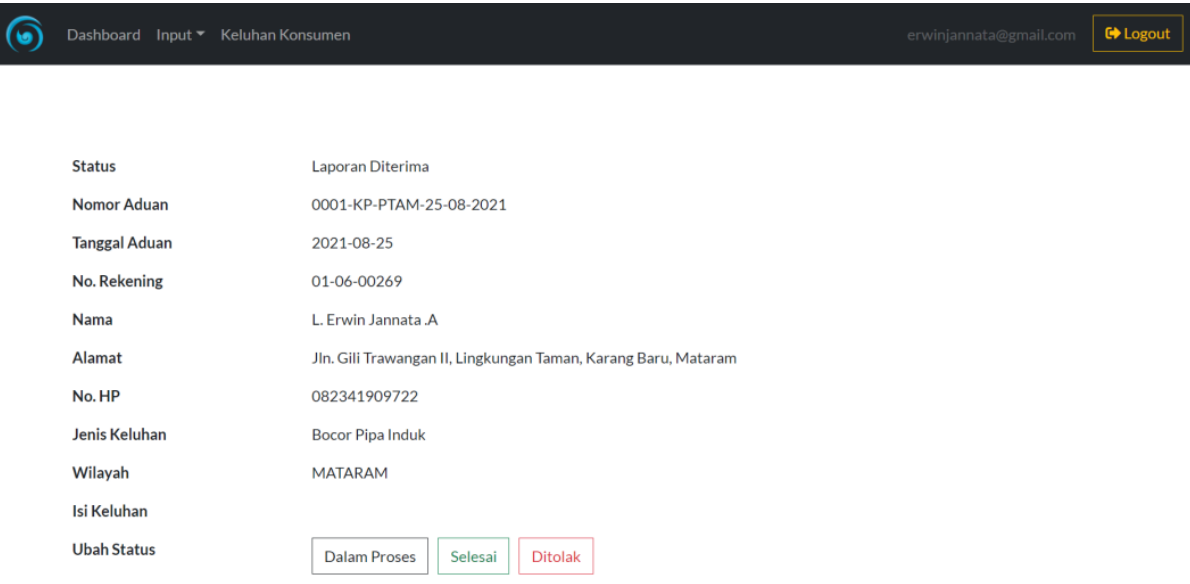

Gambar 8. Halaman lihat aduan

Gambar 8 menunjukkan bawah ada masyarakat yang mengeluhkan adanya pipa induk yang bocor di daerah Karang Baru. Setelah sistem informasi selesai dibangun, pihak PT Air Minum Giri Menang diberikan pelatihan mengenai cara pemakaianya dari sistem informasi tersebut.

\section{Check}

Pada tahap ini dilakukan evaluasi kegiatan yang telah dilakukan dan juga pada sistem informasi yang dibangun. Hasil dari evaluasi kegiatan yang telah dilakukan adalah baik meskipun terdapat kendala pada kegiatan pengujian sistem informasi yang dikarenakan banyaknya kasus yang diuji guna memastikan bahwa sistem informasi berjalan sebagaimana 
mestinya. Sedangkan untuk pengujian sistem informasi juga sesuai harapan baik dari pengujian secara fungsional maupun secara uji kelayakan. Pengujian secara fungsional dilakukan dengan menggunakan 20 kasus uji dan hasilnya sesuai harapan semua sedangkan uji kelayakan dilakukan dengan 2 kasus uji dan hasilnya juga sesuai harapan.

Pada tahap ini juga, dilakukan pengumpulan data umpan balik dari pengguna sistem informasi, untuk mengetahui kekurangan sistem informasi dalam segi pelayanan pengguna. Pengumpulan data dilakukan dengan metode survei menggunakan layanan Google Form yang diberikan kepada pengguna aplikasi. Dari proses pengumpulan data, didapatkan hasil seperti pada Gambar 9 dibawah ini :

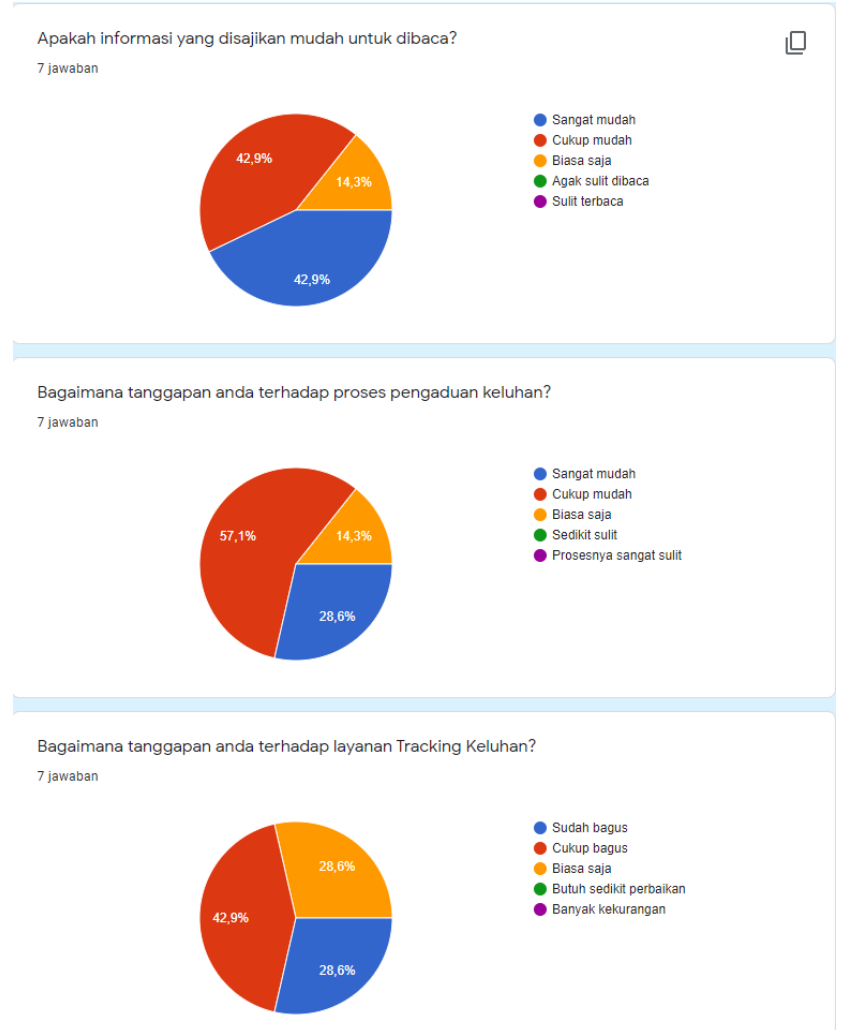

Gambar 9. Hasil survey pengguna

Responden diberikan 3 pertanyaan sehubungan dengan penggunaan sistem informasi yang dibangun. Dari data pada Gambar 9, mayoritas responden mengaku Informasi yang ditampilkan pada aplikasi mudah dibaca, dan tanggapan mengenai layanan yang diberikan cukup bagus dan mudah diakses. Berdasarkan data di atas, dapat disimpulkan bahwa sistem informasi mendapat respons positif dari pengguna.

\section{Act}

Pada tahap ini dilakukan pembuatan rekomendasi atas hasil evaluasi yang dilakukan pada kegiatan ini sehingga tujuan yang telah ditetapkan diawal dapat tercapai. Adapun rekomendasi yang diapatkan adalah melakukan monitoring terhadap sistem yang dibangun dan melakukan perawatan terhadap sistem sesuai dengan aturan yang telah ditetapkan dan https://journal.universitasbumigora.ac.id/index.php/ADMA 
kemudian melakukan lagi kegiatan perencanaan, analisis dan lain sebagainya guna meningkatkan kualitas pelayanan kepada masyarakat.

\section{Kesimpulan}

Berdasarkan hasil kegiatan yang telah dilakukan dapat ditarik kesimpulan bahwa sistem informasi yang dibangun dapat membantu pihak PT. Air Minum Giri Menang (PERSERODA) dan konsumennya dalam meningkatkan layanannya terutama untuk pengaduan keluhan dari konsumen kepada pihak PT. Air Minum Giri Menang (PERSERODA).

\section{Ucapan Terimakasih}

Tim penulis mengucapkan Terima Kasih kepada Pendamping Lapangan, Pimpinan Fakultas Teknik dan Desain Universitas Bumigora dan PT. Air Minum Giri Menang yang telah memberikan izin sehingga kegiatan ini berjalan dengan lancar. Selanjutnya, kepada peserta yang sudah antusias mengikuti kegiatan ini. Semoga dapat diterapkan secara maksimal dalam rangka meningkatkan kualitas kerja di masa yang akan datang.

\section{Daftar Pustaka}

Anam, A. K., Ridho, M., Rohman, F., Agama, K., \& Jepara, K. (2017). Implementasi sistem informasi yayasan (siyap) terhadap kualitas tata kelola keuangan yayasan pendidikan islam di jepara. Jurnal ABDIMAS Unmer Malang, 2(2), 35-41.

Dailami. (2018). Sistem Informasi dalam Pengendalian Manajemen Perusahaa. Jurnal IIman, 6(1), 5360.

Kadir, A. (2014). Pengenalan Sistem Informasi (Revisi). Andi.

Mulyono, I. U. W., Susanto, A., Rachmawanto, E. H., Sari, C. A., \& Setiadi, M. D. R. I. (2020). Implementasi E-Learning Menggunakan Edmodo bagi Guru-Guru SD Kecamatan Cawas, Klaten. Jurnal ABDIMASKU, 2(1), 56-64.

Panjaitan, J., \& Pakpahan, A. F. (2021). Perancangan Sistem E-reporting Menggunakan ReactJS dan Firebas. Jurnal Teknik Informatika Dan Sistem Informas, 7(1), 20-34.

Rawat, P., \& Mahajan, A. N. (2020). ReactJS: A Modern Web Development Framework. International Journal of Innovative Science and Research Technology, 5(11).

Rubiani, H., Samsoleh, E., Fitri, S., Soprani, S. R., \& Tasikmalaya, U. M. (2021). SEBAGAI PENDUKUNG PENERAPAN PHYSICAL DISTANCING DI MASA PANDEMI COVID- 19. BERNAS: Jurnal Pengabdian Kepada Masyaraka, 2(1), 309-316. https://doi.org/10.31949/jb.v2i1.738

Sudjiman, P. E., \& Sudjiman, L. S. (2020). ANALISIS sistem informasi manajemen BERBASIS KOMPUTER DALAM PROSES PENGAMBILAN KEPUTUSAN. TeIKa, 8(2). https://doi.org/10.36342/teika.v8i2.2327

Susanto, A., Sari, C. A., Moses, D. R. I., Rachmawanto, E. H., \& Utomo, I. (2020). Implementasi Facebook Marketplace untuk Produk UMKM sebagai Upaya Peningkatan Pemasaran dan Penjualan Online. J. Pengabdi. Masy. - LPPM Univ. Dian Nuswantoro Semarang, 3(1), 42-55. 
